ppi $201502 Z U 4645$

Esta publicación cientifica en formato digital es continuidad de la revista impresa ISSN-Versión Impresa 0798-1406 / ISSN-Versión on line 2542-3185Depósito legal pp

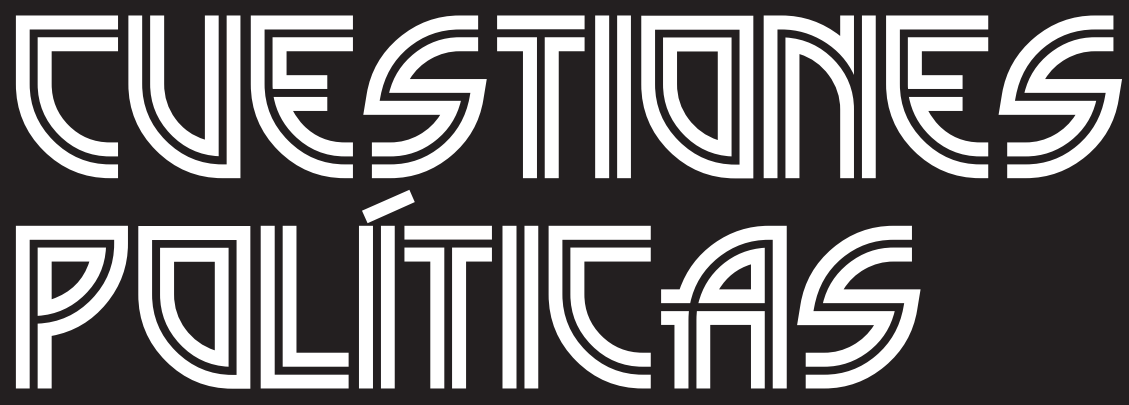

Instituto de Estudios Políticos y Derecho Público "Dr. Humberto J. La Roche' de la Facultad de Ciencias Jurídicas y Políticas de la Universidad del Zulia Maracaibo, Venezuela
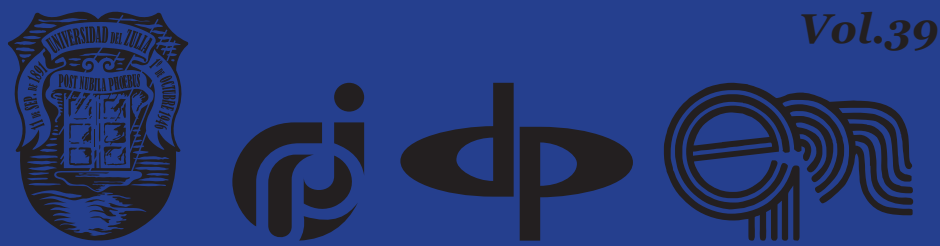


\title{
Administrative-Legal Support of Business Entities: New Quarantine Realities
}

\author{
DOI: https://doi.org/10.46398/cuestpol.3968.27
}

\author{
Maryna Slobodianiuk * \\ Inna Zhdanova ** \\ Alina Matviichuk ***
}

\begin{abstract}
The Covid-19 coronavirus pandemic has affected the world. The government is stepping up quarantine measures in its countries for the second time. Strict quarantine is beginning to be introduced in more and more countries around the world. Quarantine restrictions significantly affect businesses and limit their rights. In this regard, the issue of protection of business rights remains relevant. The purpose of the article is to study the administrative features of protection of the rights of economic entities in quarantine. The subject of the study is the social relations that arise in the protection of business in quarantine conditions. The research methodology consists of the dialectical method, historical method, system method, modeling and abstraction methods, as well as induction, deduction, analysis, synthesis and comparative law methods as a special research methods. The authors came to the conclusion that the state took decisive measures to ensure the rights of economic entities, by they significantly reflected on guarantees for entrepreneurs and in general, in particular, their ability to operate, which significantly affects the economies of countries.
\end{abstract}

Keywords: legislation; business entities; legal support; administrative law; pandemic quarantine.

* Department of Administrative and Financial Law, National University «Odesa Law Academy». ORCID ID: https://orcid.org/oooo-0002-9798-7803. Email: Ladymaryo8101993@gmail.com

** Department of Constitutional, International and Criminal Law, Vasyl' Stus Donetsk National University. ORCID ID: https://orcid.org/oooo-0002-5289-358X. Email: jdanova@donnu.edu.ua

*** Department of Economic Law and Procedure, National University «Odesa Law Academy». ORCID ID: https://orcid.org/oooo-0002-0606-7594. Email: Alina.Matveychuk@gmail.com 


\section{Apoyo administrativo-legal de las entidades comerciales: nuevas realidades cuarentenarias}

\section{Resumen}

La pandemia del coronavirus COVID-19 ha afectado al mundo. El gobierno está intensificando las medidas de cuarentena en sus países por segunda vez. La cuarentena estricta está comenzando a introducirse en más y más países de todo el mundo. Las restricciones de cuarentena afectan significativamente a las empresas y limitan sus derechos. En este sentido, la cuestión de la protección de los derechos empresariales sigue siendo relevante. El objeto del artículo es estudiar las características administrativas de la protección de los derechos de las entidades económicas en cuarentena. El tema del estudio son las relaciones sociales que surgen en la protección de empresas en condiciones de cuarentena. La metodología de investigación consta del método dialéctico, método histórico, método de sistema, métodos de modelado y abstracción, así como métodos de inducción, deducción, análisis, síntesis y derecho comparado como métodos especiales de investigación. Los autores llegaron a la conclusión de que el Estado tomó medidas decisivas para asegurar los derechos de las entidades económicas, al reflejarse significativamente en las garantías para los emprendedores y en general, en particular, su capacidad para operar, lo que afecta significativamente las economías de los países.

Palabras clave: legislación; entidades comerciales; soporte legal; derecho administrativo; pandemia cuarentena.

\section{Introduction}

The World Health Organization has confirmed that the epidemic of the Covid-19 virus has reached the level of a pandemic and called on states to take immediate action to prevent the spread of the virus. Unfortunately, the pandemic did not end with the first wave of infection. For the second time, the government is stepping up quarantine measures. Strict quarantine is beginning to be introduced in more and more countries around the world. Quarantine restrictions significantly affect businesses and limit their rights. In this regard, the issue of protection of business rights remains relevant.

The economies of countries that have not recovered from the consequences of the first quarantines, as a matter of urgency is becoming a strict quarantine. Forced transition to telecommuting, prohibition of dismissal, reduction of working hours, granting paid leave - this is a list of state requirements for business, and this is just "the tip of the iceberg". 
Ukrainian businesses felt the impact of the pandemic since March 17,2020 , as from that date they began to actively implement quarantine measures that significantly affected business rights.

Thus, the issue of introduction and functioning of quarantine is regulated by the Law of Ukraine "On Protection of the Population from Infectious Diseases" (2000), which stipulates that quarantine is established and abolished by the Cabinet of Ministers of Ukraine which can establish temporary restrictions on the rights of individuals and legal entities and establish additional obligations imposed on them. The quarantine measures also give additional powers to local governments.

Following the Resolution of the Cabinet of Ministers of Ukraine No 211 of March 11, 2020 "On prevention of the spread of coronavirus Covid-19" (with further changes) quarantine was established in Ukraine and it is forbidden to visit educational institutions, hold mass events (except for measures necessary to ensure the work of public authorities and local governments).

Also, the Ukrainian authorities adopted decisions restricting the activities of some business entities and imposing sanctions for violating quarantine measures.

The above-mentioned acts in Ukraine introduced such a special regime as quarantine and emergency, which are ensured by the introduction of restrictions on the rights of economic entities. Therefore, it is important to analyze how the regime introduced to limit the spread of Covid-19 has affected the rights of businesses in Ukraine, as well as their administrativelegal support.

\section{Methodology}

The methodology of research of administrative-legal support of the rights of business entities in the conditions of Covid-19 consists of general and special scientific methods.

Thus, a dialectical method is used to learn the essence of administrativelegal support of the rights of economic entities. Moreover, the historical method was used in the analysis of the patterns of the formation of the rights of economic entities. Further, the system method was used in the analysis of administrative and legal support of the rights of entrepreneurs as a systemic phenomenon.

What is more, the methods of modeling and abstraction were used in the process of formulating proposals to the current legislation of Ukraine. 


\section{Maryna Slobodianiuk, Inna Zhdanova y Alina Matviichuk \\ 430 \\ Administrative-Legal Support of Business Entities: New Quarantine Realities}

Besides, the study also used general epistemological methods of cognition - induction, deduction, analysis, and synthesis, which allowed investigating the administrative-legal support of the law of economic entities in the context of Covid-19 comprehensively.

Finally, the comparative legal method was used to compare the norms of national legislation and foreign legislation on the regulation of administrative-legal support of the rights of economic entities in Ukraine and the world.

\section{Theoretical framework}

At present, the administrative and legal provision of the rights of business entities in the context of Covid-19 has not been studied, as this topic is completely new in the legal environment.

Therefore, consider the work of scientists who have developed a general theoretical basis for this topic. In particular, Derevyanko and Turkot (2019) in their work analyzed the protection of the rights of economic entities. Moreover, Humin and Pryakhin (2014) analyzed different approaches to defining the concept and structure of administrative and legal support. In addition, Ierusalemova (2006) studied the mechanism of administrativelegal support of human and civil rights and freedoms. Besides, Zagnitko (2001) in his study analyzed the protection of the rights and interests of economic entities in the legal system of Ukraine. Furthermore, Kolos (2020) spoke about the rights of business entities in the conditions of Covid-19.

Also, Krivorot and Martynenko (2020) considered human rights interference during a pandemic. Besides, Nikolenko (2017) analyzed the protection of the rights and interests of economic entities in the context of legislative reform and identified key issues that should be addressed.

It should be noted that Marchenko (1998) provided general theoretical provisions on which the research is based. As well as Paliyuk (2003) considered the place of the Convention for the Protection of Human Rights and Fundamental Freedoms in the legal system of Ukraine, as well as its impact and use in the protection of the rights of economic entities.

Tsvik et al. (2002) developed the general provisions of the theory of state and law, which allowed to conduct research using different definitions of the concepts of administrative-legal support and the rights of economic entities. In addition, Shishkina (2005) considered some aspects of the legal nature of the decisions of the European Court of Human Rights and their impact on the protection of rights in Ukraine.

Also, the information used in the study is posted on the websites of various law firms, communities, including the Baykovets community 
(2020), and NGOs (Public space, 2020), and Newspapers (Legal Internet resource Protocol, 2020; Online edition Yuridichna Gazeta, 2020). Thus, from the above sites, an explanation of the activities of business entities during quarantine and how administrative liability is applied in Ukraine for violating the conditions of quarantine.

From the above analysis of the literature, we can conclude that the scientific study of administrative and legal support of business rights due to the second wave of quarantine was not conducted, but in a short period of time great interest in this topic from scientists and lawyers shows that this topic is relevant.

\section{Results and discussion}

Having analyzed how the rights of entrepreneurs are respected during the pandemic in Ukraine, it is important to consider how such rights are respected in foreign countries.

For example, in the United States, businesses have been allocated $\$ 1.8$ billion in a payroll protection program to cover wage costs, and provided that all jobs for the company are retained during quarantine, the borrowed money may not be repaid.

In Germany, there are emergency financial assistance programs for businesses that have suffered the most from quarantine.

Poland has approved a package of legislative changes to support small businesses and employees, namely: tax deferral; exemption for 3 months from the payment of the contribution to the state social insurance of small enterprises, which employ no more than nine people; compensation to selfemployed persons for termination of the activity.

Thus, EU member states direct financial resources to support entrepreneurs.

Given the above, Covid-19 significantly restricts the rights of businesses, and the state has a wide range of legislative mechanisms to combat the spread of coronavirus, which provide for the introduction of special restrictions on business.

Before analyzing the administrative-legal support of business entities in the context of Covid-19, it is important to define administrative-legal support and the rights of business entities.

The notion of "administrative-legal support" is one of the important categories of the science of administrative law. Thus, administrativelegal support is considered as one of the types of legal support, which act purposefully on the behavior of people and public relations through certain 


\section{Maryna Slobodianiuk, Inna Zhdanova y Alina Matviichuk

legal means. In general, the field of legal support covers a set of rules of management, which can and should be regulated by law and legal means, namely, security can be considered as the support of state-authorized bodies to perform their functions and as a result of this activity, expressed in the actual implementation of legal regulations, rights, and freedoms of citizens.

Regarding the administrative-legal support of the rights of economic entities, we can say that this is a complex, multifaceted, complex concept, the main content of which is the state's activities to create appropriate legal conditions for the rights of economic entities, especially in Covid-19, by the establishment of appropriate regulatory support. In this case, administrative-legal support should take place in three main areas: legal, scientific, and information.

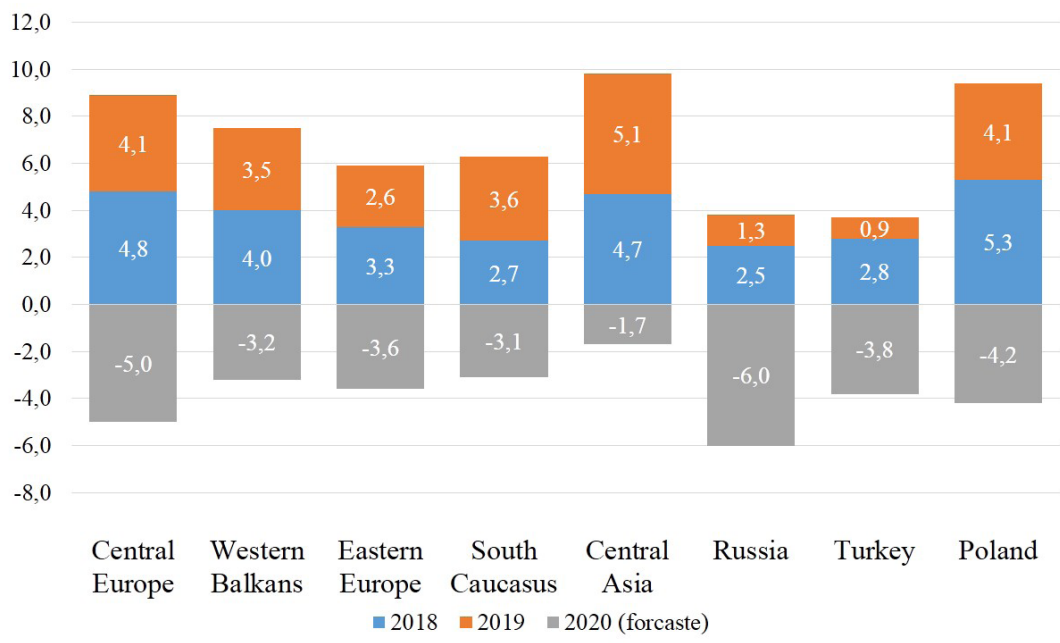

Fig. 1. Changes in GDP per capita in Europe and East Asia (20182020) (due to the application of quarantine measures).

Data provided by the World Bank (2020).

Fig. 1 shows the change in GDP per capita due to the impact of coronavirus infection and quarantine measures. Thus, South Caucasus includes Armenia, Azerbaijan, and Georgia; Eastern Europe includes Belarus, Moldova, and Ukraine; Western Balkans includes Bulgaria, Croatia, Hungary, Poland, and Romania; Central Europe includes Albania, Bosnia and Herzegovina, Kosovo, Montenegro, North Macedonia, and Serbia; and Central Asia includes Kazakhstan, the Kyrgyz Republic, Tajikistan, Turkmenistan, and Uzbekistan. Thus, as we can see on the fig. 1, there is a 
negative trend with regards to the economy of many countries, therefore, in the time of quarantine, state support for business is necessary.

As for the rights of business entities, Article 47 of the Commercial Code of Ukraine provides guarantees for entrepreneurs (Public space, 2020). Thus, the state has undertaken to provide all entrepreneurs, regardless of their chosen organizational forms of entrepreneurial activity, equal rights and equal opportunities to attract and use logistical, financial, labor, information, natural and other resources. In this case, the logistics of the entrepreneur, which are centrally distributed by the state, is carried out to perform supplies, works, or services by the entrepreneur for priority government needs.

Damages caused to an entrepreneur as a result of the violation of his property rights by citizens or legal entities, public authorities or local governments shall be reimbursed to the entrepreneur under the Commercial Code of Ukraine (2003) and other laws.

Also, the state guarantees the inviolability of property and protects the property rights of the entrepreneur, and the seizure of state and local authorities from the business entity of fixed and working capital, other property is allowed by Article 41 of the Constitution of Ukraine (1996) on the grounds and in the manner prescribed by law.

In addition, there are social guarantees, namely that an entrepreneur or citizen who works for an entrepreneur for hire, in cases provided by law, may be involved in the performance of state or public duties during working hours, with compensation to the entrepreneur of the corresponding losses by the body which makes such decision, and disputes on the compensation of losses are resolved by the court.

The rights of quarantined businesses are subject to state interference. Therefore, it is important to analyze the administrative and legal support of the rights of entrepreneurs.

The above-mentioned Resolution prohibits the work of the vast majority of service entities during the quarantine period, which provides for the reception of visitors, including catering establishments, shopping and entertainment centers, other entertainment establishments, fitness centers, cultural institutions, trade, and consumer services. Such a ban effectively deprives them of the opportunity to earn a living to meet the basic needs of them and their families, without providing any alternatives for employment or other legitimate sources of income. The conditions created by such actions of the government make it impossible for citizens to use a number of fundamental rights provided by the Constitution of Ukraine (1996), in particular, such as the right to entrepreneurial activity, which is not prohibited by law, the right to work, which includes the opportunity to earn a living by work that he freely chooses or agrees to, the right to a sufficient 


\section{4 \\ Maryna Slobodianiuk, Inna Zhdanova y Alina Matviichuk \\ Administrative-Legal Support of Business Entities: New Quarantine Realities}

standard of living for himself / herself and his / her family, including food, clothing, housing.

Therefore, it is necessary to analyze whether this is a violation of the rights of the business entity in the sense of international legal protection.

Article 17 of the Law of Ukraine "On the enforcement of judgments and application of the Case Law of the European Court of Human Rights" (2006) stipulates that courts use the Convention and the case-law of the European Court of Human Rights as a source of law when considering cases.

Thus, according to Art. 9 of the Constitution of Ukraine (1996), the Convention for the Protection of Human Rights and Fundamental Freedoms, ratified by Ukraine (hereinafter - the Convention) (1950), is part of national legislation.

Article 19 of the Convention provides that, in order to ensure compliance by the States Parties to the Convention, their obligations under the Convention and its Protocols, a European Court of Human Rights shall be established and shall function on a permanent basis. The Contracting Parties undertake to comply with the final judgments of the Court in any case to which they are parties. Under the Convention, freedom may be restricted for good reason. The articles of the above-mentioned Convention provide for interference with fundamental rights in cases where this is necessary in a democratic society to protect the health of the citizens. Article 15 of the Convention also provides for a derogation from certain rights, but only to the extent required by the provision and provided that such measures do not conflict with its other obligations under international law.

The European Court of Human Rights in its explanations on the application of Art. 15 of the Convention stated that due attention was paid to such factors as:

- the nature of the rights affected by the waiver, the circumstances giving rise to the emergency and its duration;

- whether the legislation already adopted in the country would be sufficient to overcome the threat posed by public danger;

- whether the measures are a real response to the emergency;

- whether the measures were used for the purpose for which they were authorized;

- and whether there were guarantees against abuse by public authorities.

Many scholars, both from the adversaries and from the supporters of Western civilization, pay attention to the problems with which it faced at the present stage of its development. Thus, criticized "excessive" 
democracy, the uncertainty of the boundaries of freedoms (Kharytonov et al., 2019). Nevertheless, humanity has not created a better type of social system than democracy. Only taking into account the interests of as many members of the human community as possible while adhering to clear rules and principles of coexistence can lead to the development of a full-fledged society and state (Shyshka and Tkalych, 2020).

Therefore, in the context of restricting the rights of entrepreneurs, it is necessary to establish whether there was indeed a public danger, whether adequate measures were taken concerning the threat and whether national legislation was sufficient.

Consider the state of administrative-legal support of the rights of economic entities in terms of Covid-19.

The state takes measures to ensure the rights of economic entities. Thus, under Covid-19 and the restrictions imposed during the quarantine period, the state introduced tax holidays, exemption of natural persons entrepreneurs from paying a single social contribution, as well as exempt from land tax, tax on non-residential real estate, rent for land; it is forbidden to carry out inspections of economic activity (except for the group with a high degree of risk); fines for violations of tax legislation were abolished and the deadline for filing an annual declaration of property and income was extended.

Concerning the fulfilment of obligations under contracts, during the quarantine period, it is prohibited to increase interest on the loan (including, but not limited to, the consumer's delay in the period from March 1, 2020, to May 31, 2020 fulfilment of payment obligations). However, such prohibition does not apply to cases of application of a variable interest rate, at which the lender independently, with the frequency specified in the loan agreement, has the right to increase and is obliged to reduce the interest rate under the terms and conditions established by the loan agreement. The obligation to fulfil the main obligation secured by the mortgage is also suspended, and foreclosure on the subject of the mortgage is not allowed for the period of quarantine or restrictive measures related to the spread of coronavirus disease.

In addition, until May 31, 2020, it is prohibited for state supervision (control) bodies to carry out planned measures for state supervision (control) in the field of economic activity, except for state supervision (control) of high-risk economic entities in the field of compliance requirements for the formation, establishment, and application of state-regulated prices and the field of sanitary and epidemiological well-being of the population.

It is equally important that in order to support business, the Government is improving the mechanism of the state program "Affordable Loans 5-79\%", expanding its functionality and the range of entrepreneurs who will be able to use it. 


\section{Administrative-Legal Support of Business Entities: New Quarantine Realities}

As for the quarantine itself, it can be considered a force majeure for the fulfilment of obligations under the contracts. The basis for the certification of force majeure is the presence of one or more force majeure (force majeure), as well as determined by the parties to the contract, contract, agreement, model agreement, legislative, departmental and/or other regulations that affected the obligation in such a way as to make it impossible to perform it within the period stipulated by the agreement, contract, agreement, model agreement, legislative and/or other normative acts, respectively.

Regarding the rent, following Part 6 of Art. 762 of the Civil Code of Ukraine (2003), the lessee is exempt from payment for the entire period during which the property could not be used by him / her due to circumstances for which he is not responsible. Subsequently, the legislator found that at the time of the relevant restrictive quarantine measures introduced by the Cabinet of Ministers of Ukraine to prevent the spread of coronavirus disease in Ukraine (Covid-19), circumstances for which the employer (tenant) is not responsible under part two of Article 286 Of the Commercial Code of Ukraine (2003), parts four and six of Article 762 of the Civil Code of Ukraine, there are also measures introduced by the subjects of power, which prohibit certain types of economic activity with the use of pits leasehold or measures which prohibit access to such property to third parties.

Besides, the state ensured the rights of natural persons-entrepreneurs and members of the farm who did not pay insurance premiums during the quarantine period and included these periods in the insurance period.

Thus, to ensure the rights of economic entities, the following conditions must be met:

1. Surveillance measures taken to combat Covid-19 shall be lawful, necessary, and proportionate.

2. Ukraine shall follow the principles of transparency regarding the measures taken to examine them and, if necessary, amending, revoking, or repealing them.

3. All information on changes in the rights of economic entities should be publicly available.

4. Any measures should include mechanisms for reporting and protection against abuse, and citizens should, in turn, be able to become aware of actions and challenge any Covid-19-related measures to collect, aggregate, store and further use their data. 


\section{Conclusions}

As a result of the study, the rights of business entities under Covid-19, and their administrative-legal support were analyzed.

Thus, concerning administrative-legal support the following should be stated:

Hence, concerning the fulfilment of obligations under contracts, during the quarantine period, it is prohibited to increase interest on the loan. However, such prohibition does not apply to cases of application of a variable interest rate, at which the lender independently, with the frequency specified in the loan agreement, has the right to increase and is obliged to reduce the interest rate under the terms and conditions established by the loan agreement. The obligation to fulfil the main obligation secured by the mortgage is also suspended, and foreclosure on the subject of the mortgage is not allowed for the period of quarantine or restrictive measures. In addition, many countries consider quarantine as a force majeure for the fulfilment of obligations under the contracts.

As for the administrative-legal support, the introduced tax holidays, exemption of natural persons entrepreneurs from paying a single social contribution, as well as exempt from land tax, tax on non-residential real estate, rent for land; it is forbidden to carry out inspections of economic activity (except for the group with a high degree of risk); fines for violations of tax legislation were abolished and the deadline for filing an annual declaration of property and income was extended. Besides, the state ensured the rights of natural persons-entrepreneurs and members of the farm who did not pay insurance premiums during the quarantine period and included these periods in the insurance period.

Nevertheless, the analysis of administrative-legal support of business entities under Covid-19 showed that, to avoid the spread of coronavirus, the state took decisive measures, but they significantly reflected on guarantees for entrepreneurs and in general, in particular, their ability to operate, which significantly affects the economies of countries.

Additionally, it should be noted that the topic analyzed in the article requires further research. Thus, it is necessary to analyze the peculiarities of the quarantine regime and further weaken measures for entrepreneurs through the prism of ensuring their rights, as well as the legality of such a regime, to analyze the possibility of minimizing business losses during quarantine and their administrative-legal support by state and local bodies, taking into account foreign experience, in order to make appropriate positive changes in the legislation of Ukraine and ensure the rights of economic entities at the appropriate level. 
Maryna Slobodianiuk, Inna Zhdanova y Alina Matviichuk
438 Administrative-Legal Support of Business Entities: New Quarantine Realities

\section{Bibliographic References}

BAYKOVETS COMMUNITY. 2020. Regarding the work of business entities in the conditions of quarantine caused by Covid-19. Available online. In: https://bsr1653.gov.ua/news/1585339596. Consultation date: 15/03/2020.

CABINET OF MINISTERS OF UKRAINE. 2020. On prevention of the spread of coronavirus Covid-19 on the territory of Ukraine. Resolution del 11 de marzo de 2020 № 211. Available online. In: https://zakon.rada.gov.ua/ laws/show/211-2020-\%Do\%BF\#Text. Consultation date: 15/03/2020.

CIVILCODE OF UKRAINE. 2003. Vidomosti Verkhovnoi Rady Ukrainy (VVR), 2003, No 436-IV. Available online. In: https://zakon.rada.gov.ua/laws/ show/435-15. Consultation date: 15/03/2020.

COMMERCIAL CODE OF UKRAINE. 2003. (Vidomosti Verkhovnoi Rady Ukrainy (VVR). Law 436-IV. Available online. In: https://zakon.rada. gov.ua/laws/show/436-15. Consultation date: 15/03/2020.

CONSTITUTION OF UKRAINE. 1996. Law of June 28, 1996, No. 254k / 96- VR. Revision of September 30, 2016, grounds - 1401-19. Available online. In: https://zakon.rada.gov.ua/laws/show/254\%Do\%BA/96\%Do\%B2\%D1\%80 Consultation date: 28/11/2019

DEREVYANKO, Bogdan Vladimirovich; TURKOT, Olga Andreevna. 2019. Protection of business rights. League-Press. Lviv, Ukraine. Available online. In: http://dspace.puet.edu.ua/bitstream/123456789/7002/1/ Derevyanko\%2c\%20Turkot_2019.pdf. Consultation date:15/03/2020.

HUMIN, Oleksiy Mykhailovych; PRYAKHIN, Yevhen Vasyliovych. 2014. "Administrative and legal support: concept and structure" In: Our Law. No. 4, pp. 46-50. Available online. In: http://nbuv.gov.ua/UJRN/ Nashp_2014_4_9. Consultation date: 15/03/2020.

IERUSALEMOVA, Iryna Oleksandrivna. 2006. The mechanism of administrative and legal support of human and civil rights and freedoms. Institute of Legislation of the Verkhovna Rada of Ukraine. Kyiv, Ukraine. Available online. In: http://www.disslib.org/mekhanizmadministratyvno-pravovoho-zabezpechennja-prav-isvobod-ljudyny-ta. html. Consultation date: 15/03/2020.

KHARYTONOV, Evgen; KHARYTONOVA, Olena; KHARYTONOVA, Tetiana; KOLODIN, Denis; TOLMACHEVSKA, Yuliia. 2019. "Human rights as the basic value of the concept of private law in modern Europe" In: Amazonia Investiga. Vol. 8, No. 20, pp. 477-485. 
KOLOS, Yuri. 2020. Quarantine, emergency and state of emergency: what is the difference and what restrictions can business expect? Vasyl Kisil and Partners. Available online. In: https://vkp.ua/publication/karantinnadzvichayna-situatsiya-i-nadzvichayniy-stan-v-chomu-riznitsya-tayakikh-obmezhen-chekati-biznesu. Consultation date: 15/03/2020.

KRIVOROT, Victory; MARTYNENKO, Anna. 2020. Interference in human rights during a pandemic. Online edition Yuridichna Gazeta. Available online. In: https://yur-gazeta.com/publications/practice/inshe/ vtruchannyav-prava-lyudini-pid-chas-pandemiyi.html. Consultation date: $15 / 03 / 2020$.

LAW UKRAINE. 2000. On protection of the population from infectious diseases. Law 1645-III. Available online. In: https://zakon.rada.gov.ua/ laws/show/1645-14. Consultation date: 15/03/2020.

LAW UKRAINE. 2006. On the enforcement of judgments and application of the case law of the European Court of Human Rights. Law 3477-IV. Available online. In: https://zakon.rada.gov.ua/laws/show/3477-15. Consultation date: 15/03/2020.

LEGAL INTERNET RESOURCE "PROTOCOL". 2020. Titan Law Firm. Activities of business entities during quarantine (legal analysis of regulations). Available online. In: https://protocol.ua/ua/cabinet/ yuridicheskaya_kompaniya_titan/.Consultation date: 15/03/2020.

MARCHENKO, Mikhail Nikolaevich. (Ed.). 1998. The General Theory of State and Law. Mirror. Moscow, Russia.

NIKOLENKO, Lyudmila Nikolaevna. 2017. "Protecting the rights and interests of business entities in the context of legislative reform" In: Economics and law. Vol. 47, No. 2, pp. 19-24. Available online. In: http://nbuv.gov. ua/UJRN/ecpr_2017_2_6. Consultation date: 15/03/2020.

PALIYUK, Viktor. 2003. "The place of the Convention for the Protection of Human Rights and Fundamental Freedoms in the legal system of Ukraine. Practice of the European Court of Human Rights. Decision" In: Comments. No. 1, pp. 211-224. Available online. In: http://dspace. onua.edu.ua/bitstream/handle/1130o/9776/Paliyuk\%20120-130. pdf?sequence $=1$ \&isAllowed $=y$. Consultation date: $15 / 03 / 2020$.

PUBLIC SPACE. 2020. How is administrative liability applied in Ukraine for violating quarantine conditions? Available online. In: https://www. prostir.ua/?news=yak-v-ukrajini-zastosovujetsya-administratyvnavidpovidalnist-schodo-porushennya-umov-karantynu. Consultation date: 15/03/2020. 


\section{Maryna Slobodianiuk, Inna Zhdanova y Alina Matviichuk \\ 440 Administrative-Legal Support of Business Entities: New Quarantine Realities}

SHISHKINA, Elena. 2005. Some aspects of the legal nature of the decisions of the European Court of Human Rights. In: Law of Ukraine, 9, 102-105. Available online. In: http://www.irbis-nbuv.gov.ua/cgibin/irbis_nbuv/cgiirbis_64.exe?C21COM=2\&I21DBN=UJRN\&P2 $1 \mathrm{DBN}=\mathrm{UJRN} \& Z 21 \mathrm{ID}=\& \mathrm{IMAGE}$ FILE_DOWNLOAD $=1 \&$ Image file_name=PDF/FP_index.htm_2009_1_71.pdf. Consultation date: $15 / 03 / 2020$.

SHYSHKA, Roman; TKALYCH, Maxym. 2020. The World in 2020: What are the threats to humanity? In: Amazonia Investiga. Vol. 9, No. 26, pp. 3-5.

THE CONSTITUTION OF UKRAINE. 1996. (Vidomosti Verkhovnoi Rady Ukrainy (VVR). Law 254k. Available online. In: https://zakon.rada. gov.ua/laws/show/254\%Do\%BA/96-\%Do\%B2\%D1\%80. Consultation date: $15 / 03 / 2020$.

THE WORLD BANK. 2020. Pandemic, Recession: The Global Economy in Crisis. Available online. In: https://www.worldbank.org/en/publication/ global-economic-prospects. Consultation date: 15/03/2020.

TSVIK, Mykhailo; ROGACHEVA, Victoriia; PETRISHIN, Leond; OLEYNIKOV, Oleksii; TKACHENKO, Serhii. 2002. General theory of state and law. Pravo. Kharkiv, Ukraine.

UNITED NATIONS. 1950. Convention for the Protection of Human Rights and Fundamental Freedoms. Available online. In: https://www.echr.coe.int/ Documents/Convention_ENG.pdf. Consultation date: 15/03/2020.

ZAGNITKO, Oleksii. 2001. "Protection of the rights and interests of economic entities in the legal system of Ukraine" In: Bulletin of commercial litigation. No. 4, pp. 159-166. Available online. In: http://www.library. univ.kiev.ua/ukr/elcat/new/detail.php3?docid=771122. Consultation date: 15/03/2020. 

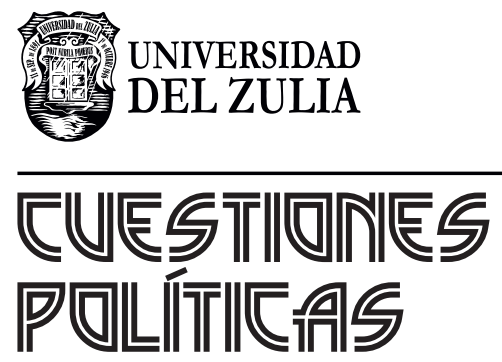

Vol.39 No 68

Esta revista fue editada en formato digital y publicada en enero de 2021, por el Fondo Editorial Serbiluz, Universidad del Zulia. Maracaibo-Venezuela 